\title{
Customer Perception towards Online Banking Service Quality - With Reference to Public Sector Banks
}

\author{
Sanuja Shree PN, S. Gurusamy
}

\begin{abstract}
This research study was aimed to explore the customer perception towards online banking adoption in Chennai city. This research study was adopted empirical and exploratory research design and structured questionnaire was used to gather the primary information from the public sector bank customers. The data collected were analysed with the help of PSPP software and statistical tools such as, percentage analysis, descriptive statistics, and multiple regression analysis has been applied to draw meaningful solutions to the research problem. The empirical evidences reveal that youngsters have higher online banking service quality perception as compared to elderly peoples. Those who are earning more income and having good occupation have higher online banking service quality perception as compared to other income and occupation groups. Public sector bank customers those who are using online banking practices before demonetization have higher service quality perception in online banking as compared to users started using aftermath of demonetisation.
\end{abstract}

Keywords:Online Banking, Service Quality, Demonetisation, Assurance and Security.

\section{INTRODUCTION}

$\mathrm{T}$ oday's Indian banking industry was more technological dependent due to growth of technological adoption in the Indian financial system (Anbalagan, 2017). The act of stripping Rs.500 and Rs. 1000 as no longer as legal tender in India was paved a way for tremendous transformation of Indian banking industry towards the adoption of cashless economy in all set of practices (Afroz, 2018). This technological growth also simultaneously increased the usage and growth of internet and smartphone penetration in the country (Wallsten, 2005). The growth and investment in technology has made online banking as an imperative aspect among all kind of bank customers in urban areas (Alt \&Puschmann, 2012). This has to be transformed to nook and corner of the country with the help of better awareness campaign and many other remedial measures to move our country towards cashless economy adoption. Online banking usage was increasing day-by-day due to the government policies and regulations with respect to financial institutions and financial system adopted in the Country. There is need to examine the online banking perception with respect to service quality dimensions fulfillment among public sector bank customers in India. Public sector banks are lacking smarter investments in

Revised Manuscript Received on December 20, 2019.

* Correspondence Author

Sanuja Shree $\mathbf{P} \mathbf{N}^{*}$, Ph.D. Research Scholar, Department of Commerce,School of Business and Management Studies, University of Madras, Chennai, India. E. Mail: sanujashree.pn@gmail.com

Dr. S. Gurusamy, Professor and Head, Department of Commerce,Chairperson - School of Business and Management Studies, University of Madras, Chennai, India E.Mail: professorsg@yahoo.com technology as compared to other private and foreign sector bank customers (Tamilselvi\& Balaji 2019). This present study focus on the service quality dimensions of public sector customers in urban area.

\section{REVIEW OF LITERATURE}

Rajesh Kumar Srivastava (2007) stated that internet banking makes the banking industry more cost effective as compared to traditional banking and the author also educated the importance of technological growth and its adoption in the realm of banking.

Sang-Lin Han (2004) conducted an empirical study to examine the consequences and antecedents of online banking service quality with the adoption of SERVQUAL instrument. The result indicates that tangibility, reliability, responsiveness and empathy are the major dimensions of service quality dimensions in the online banking adoption among customers.

Mary Loonam and Deirdre O'Loughlin (2008) explored the adoption of e-banking services among Malaysian bank customers. The researcher adopted survey method and result proves that web usability, security, trust, access and reliability are the major factors contributing for the effectiveness of service quality among Malaysian bank customers.

Rod et al.,(2009) explored the relationship between customer satisfaction and service quality dimensions among bank customers. The empirical result indicates that there is a strong positive correlation between customer satisfaction and service quality dimensions.

Mary Loonamand Deirdre O'Loughlin (2008) carried a study to examine the observations of bank customers with respect to internet banking and e-banking among Bank of Ireland customers. The result indicates that e-banking penetration and online banking growth has tremendously increased the usage and adoption of online banking perception among select bank customers in the study area. Further, the researchers found that website design is the major factor determines the e-service quality of customer's perception on e-banking.

These studies prove that there is a need to examine the perception of bank customers with respect to online banking service quality in the realm of Indian banking context. There is a need and gap to be examined the service quality dimensions among public sector bank customers in India.

\section{STATEMENT OF THE PROBLEM}

The service quality in banks is very important to have better customer relationship management practices at different functional levels of banks. 
There is a need to explore the customer perception and adoption towards online banking service quality dimensions to measure the appropriateness and applicability of service quality in online banking. The public sector banks are lacks smarter investment in technology as compared to private sector banks. This present study was aimed to explore the service quality perception among public sector bank customers in the study area.

\section{RESEARCH OBJECTIVES OF THE STUDY}

- $\quad$ To study the personal and banking profile of the public sector bank customers residing in Chennai city.

- To identify the factors and dimensions of online banking service quality perception of public sector bank customers.

- To study the influence of personal and demographic profiles of the respondents on perception towards online banking service quality.

\section{RESEARCH METHODOLOGY}

The present study was exploratory and analytical in nature and adopted survey method for the exploration of solutions to the research problem of the study. The questionnaire method with the help of non-probability convenience sampling was adopted to gather the primary information from 100 public sector bank customers in Chennai city. The data collected were subjected to Cronbach's Alpha Reliability Co-efficient and the value 0.888 proves that the scale is more consistent and highly reliable in nature. The total of 120 questionnaires was distributed to public sector bank customers and only the sample of 100 responses were finalised after the normality test and reliability test.

\section{QUESTIONNAIRE DESIGN}

Questionnaire with two sections were finalized for the main data collection. The section one deals with demographic and personal profiles of the respondents whereas, section two comprises of variables relating to the perception of customers towards online banking in the study area.

\section{RESULTS AND DISCUSSION}

The data collected from one hundred public sector bank customers were subjected to data analysis using PSPP software and statistical tools such as percentage analysis, descriptive statistics, exploratory factor analysis and multiple regression analysis has been applied to draw meaningful findings to the research study. Percentage analysis has been applied to understand the personal and banking profiles of the public sector bank customers in the study area.

The result indicates that majority of the respondents are male $(72.0 \%)$, married $(54.0 \%)$, hailing from nuclear families $(82.0 \%)$. The majority of the respondents are undergraduates $(61.0 \%)$, working in private companies $(54.0 \%)$ and earning less than Rs. 25,000 (56.0\%) as monthly income. Majority of the respondents are using banking mobile application to perform online banking activities (58.0\%) and they use at least once in a week (51.0\%) any of the online banking practices in their day-to-day life. Majority of the respondents agreed that they started using online banking after the demonetization $(74.0 \%)$ and they opined that banks $(53.0 \%)$ are the major source to create awareness among the public sector bank customers.

Table 1

Descriptive Statistics for Perception towards Online Banking Service Quality Factors

\begin{tabular}{|c|c|c|c|c|c|c|c|c|c|c|}
\hline Description & Mean & $\begin{array}{c}\text { Std. Error } \\
\text { of Mean }\end{array}$ & Median & Mode & Std. Deviation & Variance & $\begin{array}{c}\text { Skewness } \\
(\mathrm{S} . \mathrm{E}=0.321)\end{array}$ & $\begin{array}{c}\text { Kurtosis } \\
(\mathrm{S} . \mathrm{E}=0.492)\end{array}$ & Minimum & Maximum \\
\hline ERF & 9.460 & 0.238 & 10.000 & 11.00 & 2.380 & 5.660 & -0.261 & 0.034 & 3.00 & 15.000 \\
\hline WAF & 9.530 & 0.227 & 9.000 & 9.000 & 2.270 & 5.161 & 0.216 & 0.636 & 4.00 & 15.000 \\
\hline $\mathrm{CF}$ & 12.110 & 0.174 & 12.000 & 12.00 & 1.745 & 3.040 & -0.102 & -0.247 & 7.00 & 15.000 \\
\hline RSF & 14.910 & 0.248 & 15.000 & 15.00 & 2.480 & 6.160 & 0.085 & -0.621 & 9.00 & 20.000 \\
\hline $\mathbf{R F}$ & 15.090 & 0.282 & 16.000 & 16.00 & 2.820 & 7.960 & -0.069 & -0.740 & 9.00 & 20.000 \\
\hline ASF & 15.470 & 0.255 & 16.000 & 17.00 & 2.550 & 6.510 & -0.143 & -0.953 & 10.00 & 20.000 \\
\hline
\end{tabular}

Table 1 reveals that perception towards online banking service quality variables is robust in nature. The higher mean values and lower standard deviation values indicates that there is a normal distribution in the data and the distribution has a slight negative skewness. The perception towards online banking service quality twenty one variables were grouped into six factors namely, Convenience Factor, Assurance \& Security Factor, Reliability Factor, Responsiveness Factor, Website Aesthetic Factor and Easy to Recover Factor based on the scales developed by Malviya, S., Dehariya, N. and Sharma, G. (2014). The total perception towards online banking service quality variables are measured in appropriate five point Likert scale.

The Multiple Regression Analysis has been applied to study the significance of influence of Perception towards Online Banking service quality factors of the public sector bank customers and results are tabulated and presented in Table 2 . 
Table 2

Influencers of Perception towards Online Banking Service Quality

\begin{tabular}{|c|c|c|c|c|}
\hline \multirow{2}{*}{\multicolumn{2}{|c|}{ Significant Predictors }} & $\begin{array}{l}\text { Standardized } \\
\text { Coefficients }\end{array}$ & \multirow[t]{2}{*}{ t - Value } & \multirow[t]{2}{*}{ P-Value } \\
\hline & & Beta & & \\
\hline \multicolumn{2}{|l|}{ (Constant) } & & 4.877 & $<0.001$ \\
\hline \multicolumn{2}{|l|}{ Age } & 0.264 & 2.485 & $\mathbf{0 . 0 1 5}$ \\
\hline \multicolumn{2}{|l|}{ Income } & 0.304 & 2.697 & 0.008 \\
\hline \multicolumn{2}{|c|}{ Occupational Status } & -0.048 & 2.145 & 0.009 \\
\hline \multicolumn{2}{|c|}{ Demonetisation Period } & -0.280 & -3.099 & $\mathbf{0 . 0 0 3}$ \\
\hline \multicolumn{5}{|c|}{ F-Value $=23.201$ P-Value $=<0.001$} \\
\hline \multicolumn{5}{|c|}{ Dependent Variable: Perception Towards Online Banking Service Quality } \\
\hline \multicolumn{5}{|c|}{ Significant Predictors: (Constant), Age, Income, Occupation and demonization period } \\
\hline \multicolumn{5}{|c|}{ Model Summary } \\
\hline $\mathbf{R}$ & R Square & \multicolumn{2}{|c|}{ Adjusted R Square } & Std. Error of the Estimate \\
\hline 0.420 & 0.176 & \multicolumn{2}{|c|}{0.170} & 1.201 \\
\hline
\end{tabular}

Table 2 indicates that Ordinary Least Square (OLS) Model has a goodness of fit for multiple regression analysis $\{\mathrm{F}=23.201, \mathrm{p}<0.001\}$. Age, income, occupational status and demonetization period are the most significant influencers of Perception towards Online Banking service quality and they together account for $17.0 \%$ variation in it. Youngsters have higher online banking service quality perception as compared to elderly peoples. Those who are earning more income and having good occupation have higher online banking service quality perception as compared to other income and occupation groups. Public sector bank customers those who are using online banking practices before demonetization have higher service quality perception in online banking as compared to users started using aftermath of demonetization.

\section{IMPLICATIONS AND CONCLUSION}

These empirical studies explicit that service quality of online banking among public sector bank customers are on higher side. The service quality dimensions were grouped into six dimensions such as, Convenience Factor, Assurance \& Security Factor, Reliability Factor, Responsiveness Factor, Website Aesthetic Factor and Easy to Recover Factor and descriptive statistics such as mean and standard deviation values indicates that public sector bank customer's posses higher perception on online banking service quality dimensions. Age, income, occupational status and demonetization period are the most significant influencers of Perception towards Online Banking service quality. Therefore, the awareness and service quality must be focused on these aspects to improve furthermore perception among public sector bank customers. Public sector bank customers those who are youngsters, earning more income and having good occupational status have higher online banking service quality perception as compared to age, other income and occupation groups. Public sector bank customers those who are using online banking practices before demonetization have higher service quality perception in online banking as compared to users started using aftermath of demonetization. After the introduction of demonetization, majority of the customers are shown positive intent towards usage and adoption of online banking practices. The banks should provide necessary facilities and monetary benefits to online bank customers those who prefer to use digital platforms in their daily life. The banks are suggested to focus aged people and illiterate people to create more awareness and training programs to use online banking practices in every branch to increase the tendency of cashless economy adoption among public sector bank customers in India.

\section{LIMITATIONS AND FURTHER RESEARCH DIRECTIONS}

The present is limited to sample size of one hundred public sector bank customers of only State Bank of India, Canara Bank, Indian Bank and Punjab National Bank. The other public, private and foreign banks are not covered in this study. This study was only aimed to understand the perception of bank customers towards online banking service quality perception variables only. Due to time and cost constraint the study was limited to only 100 samples and non-probability sampling technique such as, convenience sample method was adopted to gather primary responses from public sector bank customers in Chennai city. So, these empirical results are not applicable to other banks. This study may be extended to private and foreign banks in India to provide more valuable insights for policy framing of Indian banking industry. Comparative study between public and private sector banks may be conducted to explore comparison between banks.

\section{REFERENCES}

1. Afroz, N. (2018). Short Term Economic Effects of Recent Demonetisation on Rural and Urban Regions: A Case of Lucknow District Of Uttar Pradesh.

2. Alt, R., \&Puschmann, T. (2012). The rise of customer-oriented banking-electronic markets is paving the way for change in the financial industry. Electronic Markets, 22(4), 203-215.

3. Anbalagan, D. G. (2017). New Technological Changes in Indian Banking Sector. International Journal of Scientific Research and Management, 5(09), 7015-7021.

4. Han, S. L., \&Baek, S. (2004). Antecedents and consequences of service quality in online banking: An application of the SERVQUAL instrument. ACR North

American Advances. 
5. Loonam, M., \&O'loughlin, D. (2008). An observation analysis of eservice quality in online banking. Journal of Financial Services Marketing, 13(2), 164-178.

6. Loonam, M., \&O'loughlin, D. (2008). Exploring e-service quality: a study of Irish online banking. Marketing Intelligence \& Planning.

7. Rod, M., Ashill, N. J., Shao, J., \& Carruthers, J. (2009). An examination of the relationship between service quality dimensions, overall internet banking service quality and customer satisfaction. Marketing Intelligence \& Planning.

8. Sharma, G., Malviya, S., \&Dehariya, N. (2014). Exploring the Dimensions of Internet Banking Service Quality in Indore. Malviya, S., Dehariya, N. and Sharma, G.(2014),'Exploring the dimensions of internet banking service quality in Indore', International LNCT Management research journal, 1, 76-79.

9. Srivastava, R. K. (2007). Customer's perception on usage of internet banking. Innovative Marketing, 3(4), 67-73.

10. Tamilselvi, R., \& Balaji, P. The Key Determinants of Behavioural Intention Towards Mobile Banking Adoption.International Journal of Innovative Technology and Exploring Engineering (IJITEE), 8 (10), 1124-1130.

11. Wallsten, S. (2005). Regulation and internet use in developing countries. Economic Development and Cultural Change, 53(2), 501523

\section{AUTHORS PROFILE}

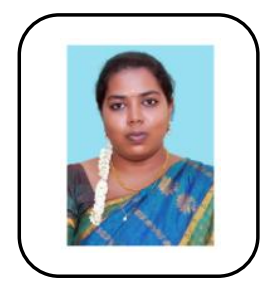

Ms. Sanuja Shree P.N is Ph.D. Research Scholar, Department of Commerce, School of Business and Management Studies, University of Madras, Chennai. She completed her Under-Graduation, Post-Graduation and Pre-Doctoral Research from University of Madras, Chennai. She was awarded University Research Fellowship from University of Madras for her doctoral research in field of Commerce and her research area is cyber banking frauds, online banking and banking technology. She is an active researcher participate and present many papers in International and National level conferences across country.

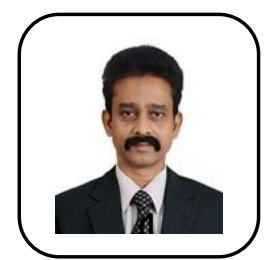

Dr. S. Gurusamy is currently serving as Professor and Head, Department of Commerce, Chairperson - School of Business and Management Studies, Chairman - Board of Studies, University of Madras. Additionally, serving as Director-inCharge, UGC - Human Resource Development Centre, University of Madras, Chennai, Tamil Nadu. He has vast experience as an administrator and academician having nearly four decades of teaching and research experience. He has specialization in the field of Banking and Finance. He authored more than thirty Books in the field of Banking, Accounting, Finance and Operations research. Under his eminent guidance More than 200 students awarded M. Phil., Degrees and 25 students awarded PhD's from University of Madras, Chennai. He has contributed More than 150 research articles in leading international and national Journals in the realm of commerce. 